\title{
Г.Ж. Мажиев
}

Египетский университет исламской культуры Нур-Мубарак, Казахстан, г.Алматы, e-mail: kmdb-apparat@mail.ru

\section{ВАИЯНИЕ ААЬ-ФАРАБИ НА ПОЭЗИЮ АРАБСКОЙ МУАРОСТИ}

Всем известен вклаА, который аль-Фараби внес в изучение не только арабской фрилософии, но и всемирной философии, в дополнение к его влиянию в ^огике, музыке, политике, медицине, математике, астрономии, классификации и других науках. Но повлиял ^и аль-Фараби на арабскую поэзию - первое арабское искусство? Основной целью данной статьи является поиск ответов на вопросы о влиянии а^ь-Фараби на арабскую поэзию и степень проявления, изучение эффектов этого влияния. Авторы исследования пытаются ответить на эти вопросы, опираясь на отношения межАу великим философом и потоком мудрости в арабской поэзии, который простирается от доисламской эры до эры Аббасидов, начиная с величайшего арабского поэта Аби ат-Тайиб альМутанабби, за которым последовали арабские поэты мудрости такие как Абу А^я аль-Маари Аостопочтенный шериф и Ибн аль-Варди в среАние века и поэты АхмеА Шавки, аль-Гохари и аль-Бардуни в современную эпоху. В исследовании использовались методы сравнительного анализа, сбор материала и классификация данных. В статье были выведены основные заключения о влиянии аль-Фараби на поэзию мудрости арабской митературы и приведены сравнительный и интертекстуальный анализы поэтических произведений.

Кмючевые слова: аль-Фараби, Господь, ислам, арабская поэзия мудрости, философия, альМутанабби.

\section{G. J. Majiyev}

Egyptian University of Islamic Culture Nur-Mubarak, Kazakhstan, Almaty, e-mail: kmdb-apparat@mail.ru

\section{The Influence of Al-Farabi on the Poetry of Arabic Wisdom}

Everyone knows the contribution that al-Farabi made to the study of not only Arabic philosophy but also world philosophy, in addition to its influence in logic, music, politics, medicine, mathematics, astronomy, classification and other sciences. But did al-Farabi influence Arab poetry - the first Arab art? The main goal of this article is to find answers to questions about the influence of al-Farabi on Arabic poetry and the degree of its manifestation, to study the effects of this influence. The study that we have in our hands is trying to answer these questions based on the relationship between the great philosopher and the stream of wisdom in Arabic poetry, which extends from the pre-Islamic era to the Abbasid era, beginning with the greatest Arab poet Abi al-Tayyib al-Mutanabbi, and for followed by Arab poets of wisdom, such as Abu Ala al-Maari, the Honorable Sheriff and Ibn al-Wardi in the Middle Ages and poets Ahmed Shawki, al-Gohari and al-Barduni in the modern era. The study used methods of comparative analysis, material collection, and data classification. The article draws the main conclusions about the influence of al-Farabi on the poetry of the wisdom of Arabic literature and provides a comparative and intertextual analysis of poetic works.

Key words: Al-Farabi, Lord, Islam, Arabic poetry of wisdom, philosophy, al-Mutanabbi.

\section{Г.Ж. Мажиев}

Нұр-Мүбарак Египет ислам мәдениеті университеті, Қазақстан, Алматы қ., e-mail: kmdb-apparat@mail.ru

\section{Әл-Фарабидың араб данамығы поэзиясына тигізген ықпалы}

Ә^-Фараби араб философияның дамуына ғана емес, сонымен қатар, жалпы философияның дамуына салмақты үлес қосқаны белгілі. О^ ^огика, музыка, саясат, медицина, математика, астрономия, жіктеу және басқа да салаларға өз үлесін қосты. А^, әл-Фараби арабтардың алғашқы өнері - араб поэзиясына әсерін тигізе алды ма? Зерттеудің негізгі мақсаты - әл-Фарабидың араб поэзиясына тигізген әсерін анықтау, оның қалай көрініс тапқанын зерделеу. Қолымыздағы бұл зерттеу жұмысы, ұлы философ пен исламға дейінгі дәуірден бастау алып, сонау Аббасилердің Аәуіріндегі атақты араб жыршысы Аби әл-Тайиб әл-Мутанаббиге дейінгі араб поэзиясындағы 
Ааналықтың арақатынасын қарастыру арқылы аталмыш сұрақтарға жауап беруге тырысады. Аби әл-Тайиб әл-Мутанаббидің ізінен ортағасырлық Абу Алә әл-Маари мен Ибн әл-Уарди және қазіргі заманның Ахмед Шауки, әл-Гохари мен әл-Бардуни сияқты арабтардың кейінгі дана жыраулары да ілескен. Зерттеу жұмысында салыстырмалы талдау, мәлімет жинақтау және мәліметтерді сараптау мен классификациялау әдістері қолданылды. Мақаланың негізгі қорытындысы бойынша әл-Фарабидың араб даналығы поэзиясына қосқан үлесі айқындалып, кейбір өлең жолдарына интертекстуалды талдау жасалынды.

Түйін сөздер: Әл-Фараби, Жаратушы, ислам, араб даналық поэзиясы, философия, әлМутанабби.

\section{Введение}

Термин «мудрость» в переводе с арабского означает «то, что обвивает пасть лошади, названное так, потому что оно мешает ему слишком быстро скакать, и делает покорным коня для его наездника, тормозит его норов» (Ибн Манзур, 1980:426), и из этого вышло общеизвестное значение мудрости. Ведь оно препятствует его обладателю попасть в низменные качества».

В то же время глагол «ахкама», который имеет тот же корень, что и «хикма» (мудрость), означает совершенствование и укрепление, предотвращение испорченности или недопущение выхода из строя (аль-Файруз Абади, 1984:253). В терминологии: «Мудрость - это слово, которое означает укрепление положения объекта на своем месте (Абу Исмаил аль-Харави, 1988:78)» или «делать то, что положено, положенным образом в положенное время» (Ибн аль-Каййим, 2003 :449).

Термин «мудрый» обозначает человека с глубокими переживаниями и тщательными наблюдениями за всем, что происходит вокруг него, от поведения людей и природы вещей до тех пор, пока у него не появится «точка зрения» в жизни, он хочет донести до других в форме очень четкого и целенаправленного предложения, чтобы его было легко понять и не нуждаться в объяснении или толковании. Также эту «точку зрения» можно легко использовать в разных жизненных ситуациях. Это суждение может быть сформулировано в форме поэтических систем, называемых «поэзией мудрости».

Обоснование выбора темы, цели и задачи

Поэзия мудрости в доисламскую эпоху «эпоху невежества»

Многие арабские поэты знали с доисламской эры поэзию мудрости благодаря тяжелому труду, горечи дней, суровости жизни, сложности ее переживаний и значительной ее переменчивости. Среди них были поэты той эпохи: аль-Самавал (ум. 560 г. н.э.), аль-Афвах аль-Ауди (ум. 570 г. н.э.), Удай ибн Зайд аль-Абади (ум. 587 г. н.э.), Зухайр ибн Аби Сальма (ум. 609 г. н.э.) и Лябид ибн Рабиа (д. 661 г.), из их уст вышли значения слов, которые брали свое начало от событий, которые они пережили (Рахима Голанян, 2019:90). Таким образом, благодаря событиям, происходящим в их жизни, формировался словарь, употребляемый в арабском обществе.

Поэзия мудрости с приходом Ислама

Поэзия мудрости продолжалась в исламскую эпоху, особенно хочется напомнить о призыве ислама, который позволил задуматься над многими вопросами, поднятыми благородными аятами Корана в душе араба мусульманина, о тайнах Божьего творения и его мудрости в создании небес и земли. А также стихи Корана призывали людей к осмыслению и назиданию, сообщая о далеких нациях и народах и посланных им небесных писаниях. Таким образом, в благородном хадисе говорится, что «в поэзии есть мудрость». Нужно сказать, что данный хадис о мудрости можно применить и в этот век.

Мудрость поэтов смешалась с их пониманием стихов Священного Корана и хадисов Посланника, да благословит его Бог и дарует ему мир. Среди поэтов мудрости того века можно выделить аль-Асвада ад-Дуали (ум. 668 г. н.э.) и Абу аль-Айяла аль-Хузали (умер при халифе Муавия).

Поэзия мудрости во времена правления Омейядов

Историки единодушно согласились с тем, что поэзия в эпоху правления Омейядов была усовершенствованием доисламской литературы (Джирджи Зейдан, 1996:223), поскольку арабская поэзия продолжала извлекать свои значения из арабской среды и из того, что Священный Коран и пророческие хадисы добавляли к значениям из-за влияния исламского призыва и того, что поощряло благой нрав. Одной из целей этих стихов мудрости был призыв к аскетическому образу жизни и стремление к благодеянию (Шавки Дейф, 1989:369). Поэзия в эти времена 
отличалась простотой формулировки, простотой структур, ясностью смыслов и их близостью, а также отсутствием сложности и неоднозначности. Среди поэтов этого направления были хорошо известны Хасан аль-Басри (ум. 728), Абдулла бин Мубарак (ум. 797), Махмуд аль-Уаррак (ум. 844) Имам Шафи (ум. 820), аль-Халил бин Ахмед (786), Абу аль-Атахия (ум. 826) и Мухаммед ибн Ясир аль-Рияши (ум. 833).

\section{Поэзия мудрости в эпоху Аббасидов}

Поэзия мудрости расцвела в эпоху Аббасидов беспрецедентным образом в арабской поэзии в результате развития в ней арабского сознания благодаря контакту с другими цивилизациями и переводу иностранных книг. Отмечается, что поэты Аббасидов впитали в себя мудрость Греции и персов и мудрости индийской Калилы и Димны, которая была переведена на персидский язык, а затем переведена Ибн аль-Мукаффой на арабский язык. В ту эпоху поэзия мудрости отличалась смешением идей, созданием смыслов, погружением в идеи и уделением внимания деталям, анализу и рассуждениям. Поэзию мудрости во времена Аббасидов отличали отдельные стихи или полные отрывки мудрости, в которых поэт движется от трона стихийного поэта к престолу ан-Назим аль-Муаллим (поэт учитель). Из поэтов мудрости в эту эпоху можно выделить Абу Таммама, Башшара ибн Бурда и Салеха Абд аль-Куддуса. Они те, кто поднял поэзию мудрости на недосягаемый уровень в истории арабской литературы в результате развития знаний и распространения науки.

\section{Научная методология исследований}

\section{Век аль-Фараби}

В четвертом веке по хиджре/в десятом веке по Григорианскому календарю нашей эры наступает эпоха расцвета восточных знаний и цивилизации, поскольку она стала свидетелем интеллектуальной, научной и лингвистической революции, в ходе которой были распространены книги и произведения и появились великие восточные цивилизации, как об этом пишет профессор восточных языков Базельского университета в Швейцарии Адам Мец в начале двадцатого века в своей книге «Исламская цивилизация в четвертом веке хиджры. В этом столетии именами ученых, писателей, философов, врачей, математиков, химиков, историков, географов, богословов и лингвистов обогатились исламское и мировое наследие, которое сохраняется и по сей день. Самые видные из них: Халиль ибн Ахмад, Абу Ис- хак аз-Зуджадж, Абу аль-Ляйс ас-Самарканди, Абу Бакр аль-Калябази, Ибн аль-Гамид, Ибн ан-Надим, Ибн аль-Хайтам, Кудама ибн Джаафар, Абу аль-Хассан аль-Ашари, Абу Бакр аль-Бакилани, Абу Мансур аль-Матриди, Абу Хилал аль-Аскари, аль-Хаким ас-Самарканди, Даракутни, аш-Шариф Рида Сахиб ибнн Гимад, ат-Табарани, Кади Абд аль-Джаббар, Абу альХасан ат-Табари, Абу Бакр ар-Рази, аль-Балхи, аз-Захрави, Куста ибн Люка, Абу аль-Райхан аль-Бируни, Абу Хамид ас-Сагани, Абу Заид аль-Балхи, Ибн Юнис аль-Масри, Абу аль-Вафа аль-Бузджани, Абу Махмуд аль-Худжанди и многие другие, кто повлиял на Исламское мировоззрение сокровищами познания. Самым видным из них является Абу Наср аль-Фараби, который повлиял не только на арабскую мысль, но и на мировую цивилизацию. Его наследие можно увидеть во многих областях цивилизации, таких как философия, логика, музыка, политика, медицина, математика, астрономия, классификация и другие области. Но считается ли след ментальной науки аль-Фараби нововведением и повлиял ли он на арабскую литературу, являясь тюрком по происхождению?

Арабский язык не был чужд аль-Фараби, поскольку он знал его и говорил на нем, как и на многих других языках, а также поскольку он изучал грамматику и риторику и получил образование от Ибн ас-Сарраджа (аль-Кафти, 1950:149), который был известен своей причастностью сразу двум школам в грамматике Куфы и Басры. Также он был во взаимосвязи с писателями и лингвистами в его эпоху, такими как ат-Таухиди и ас-Сиджистани. Это дало ему глубокую лингвистическую культуру, которая отражена в различных трудах, дошедших до нас, где арабские книги были адаптированы к различным типам знаний, так что его словарный запас вышел за рамки распространенной лексики в науках своего времени и знаний. Таким образом, он написал свое научное и философское наследие, а точнее он написал книгу, которая является энциклопедией на арабском языке, это книга «Буквы», и кроме того, аль-Фараби был вовлечен в нововведения этого поэтического языка, поэтому он написал книгу «Сборник поэзии» (Мохамед Селим, 1971), в которой он показывает свои глубокие знания правил арабской поэзии, его инструментов и эстетики. Аль-Фараби приписывают стихи, организованные на арабском языке, в которых преобладают мысли и мудрость по методу философов и мыслителей, включая его высказывание: 
Господь всех звезд, покрытых днем,

Которые били ключом словно реки,

Они исполняют Его волю,

Которая охватывает все сущее,

Стал просить у Тебя блага

Не признавая Сатурн, Юпитер и даже Меркурий

(Салих ад-Дин аль-Сафди, с. 111)

\section{А также слова:}

О, Причина всех вещей, от щедрости

Его произошли моря!

О Господь небес, взаимосвязанных друг с другом, посередине центр всех морей в изобилии

Молил Тебя, прося убежища, ведь грешник я, прости ошибки грешника небрежного,

Очисти своей щедростью грязь природы и все его элементы

(Салих ад-Дин аль-Сафди, с.111)

\section{Также эти строки:}

\author{
Мой брат, это ложное пространство \\ Все в пределах фактов, \\ Что для нас является домом бессмертия? \\ Не слаб на земле человек, \\ Мы только строки, написанные на шаре готовом, \\ И тот с этим соперничает хотя бы словом кратким, \\ Небеса достойнее нас, и среди них есть скопление \\ достойных (Ибн Фадлаллах, 1951:42)
}

Несмотря на ясность мудрости в этих стихах, влияние аль-Фараби на поэзию его времени и поэзию последующих эпох превосходит влияние его поэзии, ведь это не просто влияние одного поэта на другого. Его влияние гораздо глубже. Можно сказать, что аль-Фараби был воротами в греческую философию, особенно в труды Аристотеля для мусульманского разума. Аристотель не знал исламскую культуру до окончания кампании по переводу, проведенной халифом альМамуном, и, скорее всего, это было сделано Ханином и его сыном Исааком в 298 г. хиджры. И что переводческое движение в эпоху правления аль-Мамуна сначала занялось книгами Аристотеля, не посвященными логике, которые задержали истинное начало исламской философии.

Хотя Якуб ибн Исхак аль-Кинди (805-87) был первым мусульманином, который попытался использовать логический подход и написал «Сообщение в первой философии», в котором он попытался защитить и оправдать философию от позиций юристов (богословов) и ораторов и защитить ее от нападавших, но его усилия, сделанные на пути понимания и утверждения аристотелевской мысли, в целом не оправдались (Мухаммад Абд аль-Джабри, 2019:66). Одна из причин - недостаточное количество книг Аристотеля. А также его главная забота была о религии (Мухаммед Абд аль-Хади Абу Рида, 1950). Они пытались согласовать религиозную истину с метафизикой. Аналогичным образом, усилия Абу Бакра ар-Рази (864-923 гг.), который отказался вовлекать религию в дела разума и был убежден, что опора на религию не является плодотворной из-за различных религий в своих взглядах на творение и на то, что есть истина (Абдул-Азиз аль-Шаркави, 2013: 61). Но он не смог представить и упростить философию для простого человека вместо этого, весь упор был сделан на связь ее с элитой.

Принимая во внимание, что в своих трудах аль-Фараби сумел приблизить философию к простому человеку, связал ее со своими интересами и очень легко протянул руку своему читателю, вводя в мир философии, как он сделал это в своей книге «Взгляды народа утопии», где альФараби в книге «Республика» подошел к идее Платона о том, что лидером идеального общества должен быть философ, который правит по законам разума и логики.

Подобно тому, как аль-Фараби приблизил философию к обычному человеку, он также сблизил перевод арабских произведений с трудами греческих философов в области истинной философии. Переведенные книги по философии до аль-Фараби содержали в себе много непонятных ошибок. Будучи знатоком семидесяти языков, в том числе персидского, арабского, турецкого, греческого, а также сирийского, аль-Фараби был первым, кто стал на путь изучения и преподавания всех книг и мыслей Аристотеля и Платона на высшем уровне. Он отдал много сил этому делу. Затем он коснулся объяснения, критики и комментирования. Мы можем даже сказать, что мировое знание взглядов и работ этих двух философов является ничем иным, как следствием знания альФараби и его напряженных усилий на этом пути, особенно после того, как он оказался при дворе правителя Сайфа ад-Даула аль-Хамадани.

Сайф ад-Даула ибн Хамдан, основатель эмирата Алеппо, прославился своим покровительством в области искусства и науки и поощрением писателей, исследователей и философов, что объясняет существование такого большого числа писателей и мыслителей, которые пережили время, в том числе Иса ар-Раки, Абу Бакр Мухаммад ибн Закария ар-Рази - величайший врач ислама, и самые выдающиеся астрономы и математики, появившиеся в эпоху аль-Хамадани в Леванте, Абу аль-Фарадж аль-Исфахани, автор «Песен», 
и поэты Ибн Набата ас-Саади, Абу Фирас альХамадани, Абу аль-Аббас ан-Нами, Ас-Сирри ap-Рафа, Кашаджим, аль-Халдиан, и Вава адДимашки, Жаграфи, Ибн Хавкал аль-Маусалий, автор книги «Пути и государства», Абу Али альФариси, Ибн Халауайх, аль-Хауарезми и другие, и столица его страны Алеппо стала местом для ученых, писателей и философов, во главе которых был аль-Фараби.

Аль-Фараби присоединился к двору Сайфа ад-Даула в 941 году по хиджре, и ему было около семидесяти лет. Сайф ад-Даула знал добродетели аль-Фараби и почитал его присутствие. Его почтение выросло и аль-Фараби жил на его попечении, отдав всего себя преподаванию и сочинению книг. Таким образом, он достиг вершины славы во дворце Сайф ад-Даула аль-Хамадани. Его книги стали популярными, достоинство почтенным, увеличилось количество его учеников. Сайф ад-Даула держал литературные салоны, заполненные учеными, лингвистами и писателями. И аль-Фараби был в центре них, участвовал в дискуссиях на различные темы.

Аль-Мутанабби - поэт эпохи

Среди выдающихся людей XX-го века (4-го века по Хиджре), которые украшали заседания Сайфа ад-Даула, мы находим Абу ат-Таййиба альМутанабби, которого многие считают неоспоримым эмиром поэтов четвертого века, а некоторые считают его самым великим арабским поэтом. У него был высокий статус, которого никогда не было у других арабских поэтов. И многие считали его редкостью и чудом своего времени.

Несмотря на то превосходство поэзии альМутанабби, который писал на различные темы, его лучшие труды связаны с поэзией мудрости и философией жизни. Он - обладатель различных образов, красноречивых мудрых высказываний и оригинальных смыслов. Особенно он прославился как поэт мудрости, ведь он много писал о ней. Кроме того, читатель поэм аль-Мутанабби заметит, что стихи, написанные им в юношестве, лишены мудрости. Даже те строки, которые затронули мудрость, были очень простыми (Хамед Тахер, 2014:1). Но, если взглянуть на стихи аль-Мутанабби, когда он был во дворце Сайфа ад-Дауля в Алеппо, мы находим другие, более глубокие и проницательные слова мудрости. В чем же причина такого преобразования?

\section{Результаты и обсуждение}

Встреча философа и поэта

Возможно, развитие поэзии мудрости альМутанабби связано не с одним фактором, а с несколькими причинами, такими как накопление знаний и жизненного опыта, большое количество путешествий, но все эти факторы были доступны также для других поэтов его времени. Вероятно, был еще один фактор, который оказал большое влияние на его жизнь и сознание. Он нашел его во дворце Сайфа ад-Даула аль-Хамадани, в 948 году по Хиджре. Тогда ему было около 33 лет, что означает, что встреча альФараби и аль-Мутанабби во дворце Сайфа адДаула была в пределах одного или двух лет до смерти аль-Фараби, который умер в 950 году по жиджре. Эту связь между ними аль-Мутанабби описывает только в одной поэме (касыде) хвалебными словами в адрес философа и элегией, посвященной его смерти. Мы даже не увидим в стихах поэта ни слова в адрес философа во время литературных собраний во дворце Сайфа адДаула. Несмотря на все это, большинство исследователей, изучавших поэзию аль-Мутанабби, указывали на явное влияние аль-Фараби на стихи поэта (Мухаммад Мандур, 2007:66). В связи с этим возникает ряд вопросов: об отсутствии упоминаний аль-Фараби в сборнике стихотворений аль-Мутанабби и о том, как великий философ повлиял на поэта, и проявлениях этого влияния.

Первое: Отсутствие упоминания аль-Фараби в сборниках аль-Мутанабби можно объяснить тем фактом, что они узнали друг о друге, когда аль-Фараби уже исполнилось семьдесят четыре года, и он предпочитал аскетический образ жизни. Он не вел праздную жизнь, жил на четыре дирхама в день и даже не обращал внимания на свой внешний вид. У него даже не было семьи, чтобы найти утешение, и титула, который можно потерять. Почему же аль-Мутанабби и другие поэты должны восхвалять его?!

Bторое: Отсутствие похвалы или причитаний аль-Мутанабби не означает отсутствие его влияния на него, так как существует группа факторов, которые помогли этому влиянию, такие как наличие большого сходства между двумя личностями, оба из которых имеют происхождение бедуинов, родившихся в пустыне, и оба переселились в другую страну в молодом возрасте. Отдаленные соотечественники, страны, поиски науки и знаний, побег из стран, где их притесняли. Оба гордились своей индивидуальностью (Мухаммед Абд аль-Хади Абу Рида, 1967:206), оба были выше низких поступков, далеки от развлечений и распущенности, и ни один из них не был любителем уюта и пустоты, оба провели лучшие дни жизни во дворце Сайфа ад-Даула аль-Хамадани в Алеппо. 
Аль-Мутанабби был образован, обладал широкой культурой со всеми знаниями и мнениями, известными его времени, и поэт подолгу сидел с книгами, проводя ночи с ними. Его самое знаменитое высказывание:

Самое почтенное место в жизни - седло скакуна,

А самый хороший собеседник за все время - книга!

Его обширные знания позволили ему применить в своей поэзии эти знания и мнения и вызвать восхищение ученых и интеллектуалов его эпохи, и он использовал для этого язык и удивительные методы (Шавки Дейф, 335), и, должно быть, аль-Мутанабби, хорошо осведомленный интеллектуал, читал книги аль-Фараби, в дополнение к его присутствию Он находился при дворе Сайфа ад-Даула, что повлияло на личность амбициозного поэта. Подтверждает влияние философии аль-Фараби на поэзию аль-Мутанабби то, что последователь наблюдает в поэзии альМутанабби отсутствие мудрых высказываний в начале его жизни, и, если они даже существуют, они характеризуются простотой, и причина этого - бедуинская жизнь, которую он прожил в юности. Когда же он переехал в Алеппо и встретился с великим философом, у него появилась возможность познакомиться с наследием других цивилизаций. И тогда его стихи мудрости становятся более разнообразными и глубокими (Шаллуф Хуссейн, 2005:82).

Tретье. Можно сказать, что поэзия мудрости стала свидетелем значительного сдвига в эпоху Аббасидов, и эта трансформация была достигнута трудом Абу ат-Таййиба аль-Мутанабби, поскольку в литературных кругах в древние и современные времена говорится, что альМутанабби был одним из самых выдающихся арабских поэтов, отличившихся в поэзии мудрости. Поэты говорят, что он также отличался особым стилем писания стихов. Любой, кто взялся читать его поэзию, может отличить новый поток поэзии мудрости, который представляет собой поэзию философской мудрости, которая отличается от предыдущего потока, и которую мы можем назвать превосходящей религиозную мудрость, и основным отличием между ними является культурный ориентир для каждого из них. Мысли первого проистекают из текстов Священного Корана и высказываний Пророка Мухаммада (мир ему), а также арабского наследия, у другого мысли берут свое начало у философов и учтителей логики. Аль-Мутанабби был открыт философской культуре своей эпохи, в которой аль-Фараби достиг наивысшую из своих вершин, так что его считают самым лучшим арабским поэтом, прославившим философскую мудрость посредством своих стихов. Даже его сторонники и противники сошлись во мнении, что он явно находился под влиянием философии в своей поэзии (аль-Хатами, 23). Историки подтверждают это, указывая на то, что он тонко мыслил, делал много выводов, был мастером в сочинении, приводил много пословиц и измерял подобия сходств (Мухаммед Камаль Хилми Бей, 1921:232). Аль-Мутанабби назвал себя мудрым (ас-Субх аль-Мунабби, 102), сказав:

Язык у него арабский, мысли философские, привычки персидские

Аль-Мутанабби характеризовался глубиной смыслов и идей, которые он записал на основании мудрости своей поэзии, которые стали примерами и поговорками, и часто встречаются на устах людей. Аль-Мутанабби считает, что он передал философию в поэзии в тот день, когда она искала путь к арабскому уму, и, возможно, поэт аль-Мутанабби был одной из причин, по которой писатели и поэты занялись философскими исследованиями, чтобы дополнить свое искусство и желая догнать этого поэта-философа, так что аль-Мутанабби действительно считался основателем потока философской мудрости, в котором его поклонник и последователь философ, поэт Абу-ль-Аля аль-Маари, автор книги «Чудотворец Ахмад» собрал антологию стихов. Аль-Маари считал поэзию аль-Мутанабби кратким изложением греческой философии, когда он комментировал в двух строках аль-Мутанабби:

Друг, этот воздух попал в души,
дал почувствовать вкус смерти
Печаль перед смертью - это слабость,
ведь оно только после смерти.

И сказал он:

«Эти строки посвящены двум греческим книгам, так как они предельно точно описывали мысль. Ведь даже если не было бы других книг, эти две были достаточны ему».

Ясно, что аль-Мутанабби был впечатлен аль-Фараби в его мнении о значимости ума, поскольку аль-Фараби считается одним из самых важных философов, которые были заняты изучением ума и его типов (аль-Фараби, 1986:12) и показывали его влияние на человечность людей, что показано в стихах аль-Мутанаби: 
Мнение впереди храбрости храбрых,

Оно на первом месте, а храбрость на втором

Они собираются в свободной душе, которая взяла все высоты.

Если бы не умы, то честь человека пала бы в низ нищеты.

У аль-Мутанабби есть одна строка, в которой он проводит различие между сломленным умом и активным умом, как будто он объясняет теорию аль-Фараби, которая фактически разделяет ум на силу и действие:

Все утверждают как вы, что ум всегда в порядке,

Как же можно познать свое невежество?!

Аль-Мутанабби подчеркивает значение разума в жизни человека, чтобы привести сердце к правильному решению, и он говорит:

У сердца должен быть инструмент и мнение,

Которым рассечет глухоту камней.

Возможно, читатель думает, что аль-Мутанабби в своем знаменитом стихе нарушил теорию счастья аль-Фараби, в которой тот связал счастье с разумом (Саид Аль-Джабли, 71), а текст стихов аль-Мутанабби гласит:

Обладатель ума страдает в блаженстве,

А невежда в несчастье радуется!

И он видит, что «разум» как божественный дар и божественная благодать может быть вредным для его владельца, он может утомить его и вызвать у него трудности, и он не почувствует вкус жизни или ее удовольствие, поскольку он думает обо всем и анализирует это, и для него важно учитывать последствия дел и изучать ситуацию, прежде чем что-либо потерять, и это заставляет его потерять то, что ценно. Почему бы нет, когда он видит, как аль-Фараби провел всю свою жизнь в аскетизме. Он даже не женился, а предпочел жить один, и он был не в состоянии добыть какую-либо сумму денег и брал только четыре дирхама в день от Сайфа ад-Даула, чтобы удовлетворить свои основные потребности.

Существует сходство между мнением философа и мнением поэта в вопросе «характера», с которым человек появляется и не может быть изменен, поэтому аль-Мутанабби говорит в некоторых своих стихах: «И нравы несовместимы с носителем», и он говорит:

Наилучшее, что требуется для достижения успеха, характер,

И углубление в свои промахи!
Аль-Фараби поднял в книге «Объединение двух мудрых мнений» проблему спора между Аристотелем и Платоном, заключающуюся в том, что все морали - это изменяющиеся привычки, и что ни одна из них не связана с врожденными качествами, и что морали могут переходить от каждого из них к другому посредством привычки и обучения, как сказано в словах Аристотеля, или что врожденные качества одерживают верх над привычками, как Платон упомянул в книге «Политика».

В поэзии аль-Фараби и аль-Мутанабби имеется поэтическое сходство. В стихах аль-Фараби есть значения, которые присутствуют в поэзии аль-Мутанабби. Возможно, то, что аль-Хатими упомянул в своем письме высказывания, которые приписываются Аристотелю, с которыми согласился аль-Мутанабби, могут быть словами аль-Фараби. И Хатими не указывает ссылки на Аристотеля, что может послужить доказательстваом тому, что учения Аристотеля дошли до него через аль-Фараби. Историки говорят, что у аль-Фараби есть книга под названием «Сборник отрывков из слов древних», и что эта книга не дошла до нас, как и остальные пропавшие книги аль-Фараби. Вкратце можно сказать, что аль-Мутанабби является последователем альФараби в его философии. И мы находим, что у философа и у поэта одинаковое поэтическое видение. Аль-Фараби говорит об этом:

В то время, когда увидел в эпохе страдания, и не было пользы от беседы,

У всех правителей усталость, а в головах боль,

Решил остаться дома и сохранил честь довольством от самолюбия,

И выпил сполна из того, что осталось от вина, в свое удовольствие.

В их бутылках для меня собутыльники, а от ягненков слушание,

И буду срывать плоды из разговоров людей, кто выкопал их местность (Ибн Фадлаллах, 1951:42)

Тревожась за людей и время, аль-Мутанабби говорит:

Тот, кто познал дни так же, как я, и что происходит с людьми,

Не раскаиваясь, ударил бы копьем

\section{А в другом стихе говорит:}

И жили люди до нас в те времена, и заботы у них были, как и у нас есть заботы,

И приняли всю печаль на себя, даже если некоторые были рады иногда, 
Может быть, темнота ночей сокроет поступок, но благодетель они точно загрязнят!

Мы находим некоторые из смыслов аль-Фараби, организованных в поэзии альМутанабби, таких как высказывание альФараби: «И каждое существо, в соответствии с Его повелением, предопределением, также вред находится в Его власти и предопределении» (аль-Фараби, 1931:18). И близко к этому высказывание аль-Мутанаби:

Аллах делает то, что желает,

И возможно, что он может пожелать и вред!

В поэзии аль-Мутанабби мы находим повторение мысли аль-Фараби, которая отвергает астрологию, которая была распространена в эпоху Аббасидов до такой степени, что и халифы любили астрологию, так что некоторые из них консультировались с астрологами в вопросах управления и преемственности. Они делали это для того, чтобы укрепить сой трон навечно и доказать, что их приход к власти - это воля Вселенной. Конечно же, это вселило отчаяние в сердца оппонентов, ведь если звезды и планеты говорят и доказывают, что власть принадлежит Аббасидам, то что могут сделать противники (Абир Аль-Аббаси, 2017:4)?! В этих обстоятельствах мы обнаруживаем, что аль-Фараби противоречит тенденции, преобладающей в его эпоху, в том числе халифам, принцам и многим ученым своего времени, когда он признал недействительность астрологии и написал письмо, выражая в нем свое мнение, озаглавленное «Шутки о том, что правильно, а что нет» относительно правил звезд, и аль-Фараби объяснил, что знание, которое зиждется на положение звезды, является непригодной, поскольку эта наука приписывает все сверхъестественное и возможное звездам и планетам. Он выявил ошибки многих, кто утверждал, что планеты приносят сглаз или счастье. Мы видим, что аль-Мутанабби выражает это в своем высказывании:

Да пропадет религия, где поклоняются звездам,

И говорят, что они разумеют!

И мы находим аргументы Аристотеля, организованные в поэзии аль-Мутанабби, когда он говорит: «Болезнь умов хуже болезни тел». Поэтому аль-Мутанабби упорядочил это значение посредством поэзии, сказав:
Для нас легко почувствовать тела, и повинуются нам акиденции и разум

Мы находим значение высказывания Аристотеля: «Если душа не отклоняется от своих низменных желаний и намерений, то ее жизнь это смерть, а ее существование - небытие». АльМутанабби донес это в стихах и сказал:

Унизился тот, кто завидует жизни, возможно, что смерть для него легче жизни

Аль-Хатами Абу Али Мухаммед ибн альХассан аль-Музафар аль-Багдади (310 г. хиджры / 922 г. - 388 г. хиджры / 998 г.) написал письмо, в котором он сравнил стихи аль-Мутанабби с высказываниями Аристотеля, и в своем письме он собрал сотню мест, в которых Абу Таййиб согласился с высказываниями «Первого учителя».

Распространенность фраз философов и логиков в его поэзии, таких как его высказывание в описании кобылы: «Она быстра и у нее есть знаки», и он сказал:

Если чашка трясет руки,

Я проснулся, а ее нет между мной и мной

\section{А также слова:}

Если что-то удлинилось само по себе, прочистился луч солнца, и оно оказалось ложным

\section{Также слова:}

Я встретил с радостью некоторых врагов и наткнулся на пастбище

И слова:

Да исцелит тебя тот, кто лечит своим великодушием творения, Ты - море, а остальные моря лишь часть тебя

И слова:

Слова тленны, чтобы обьять ваши достоинства, как же тленное может обьять вечное

А также слова:

Мы просим невозможное, нигде и недостижимое

5. Много упоминаний имен философов, таких как: Аристалес, Птолемей, Гален и Хатрат в своей поэзии, поэтому он говорит, например, в своей похвале визирю Ибн аль-Амиду: 
Достигнув предела у арабов, я составил компанию Аристалесу и Александру, и слушал как Птолемей преподавал книги жителю пустыни, королю и городским.

И слова:

Когда нашел лекарство от своей болезни, мне стали легки качества Галена

6. Тонкость значений его поэзии, как утверждают критики, указывает на то, что альМутанабби находился под влиянием философии, и он намеренно отвлекал от смыслов. Аль-Аккад считает, что поэзия аль-Мутанабби возникла по образцу, который отличается от метода философов только жаром эмоций и характером (Аббас аль-Аккад, 2009:145). Аль-Аккад сравнивает высказывания аль-Мутанабби с философией Фридриха Ницше (Аббас аль-Аккад, 2009:155). Профессор Шафик Джабри видит множество философских подходов в поэзии аль-Мутанабби (Шафик Джабри, 1930:174). Махмуд Мохамед Шакер утверждает, что Абу Таййиб был затронут доступной философией своего времени и что он прибегал к философским методам в извлечении и создании значений. Поэт говорит:

И я обнаружил, что был так скуден на счет конца веселья и плача

\section{И слова:}

Ваши качества в глазах создали его слова, как почерк заполняет мой слух и взор.

\section{Заключение и выводы}

Аль-Мутанабби с поэзией мудрости достиг вершины арабского творчества и смог вызвать поток подражателей, следовавших за ним на его пути во главе с Абу-ль-Ала (ум. 1057 г.), для которого аль-Мутанабби был источником поэзии (Шафик Джабри, 1930:168). Он был учеником одного из его передатчиков, и он следовал его подходу, чтобы обогатить свою поэзию философией. Его даже назвали «поэтом философов и философом поэтов» (Мухаммед Курд Али, 1910).

Поток философской мудрости не ограничивался Абу-ль-Ала аль-Маари, но также включал в себя группу корифеев арабской поэзии, таких как: аш-Шариф аль-Рида (ум. 1015 г.), альТуграи (ум. 1121 г.) и Ибн аль-Варди (ум. 1349 г.), а также в современном мире Махмуд Сами альБаруди (ум. 1904 г.), Ахмед Шавки (ум. 1932 г.), Мааруф ар-Русафи (ум. 1945 г.), аль-Джавахири (ум.1997 г.), аз-Захави (ум. 1936 г.), Халил Хави (ум. 1982 г.), аль-Бардуни (ум. 1999 г.) и другие.

И изучающему арабскую литературу необходимо перечитать наследие аль-Фараби и рассмотреть произведения этих поэтов и других, которые писали с целью философской мудрости, чтобы обнаружить влияние аль-Фараби на их поэтические значения и увековечить память об арабе Абу Таййибе аль-Мутанабби, этом уникальном философе, который обогатил арабскую мысль и литературу и распространил ее влияние на протяжении поколений и столетий через врата его мысли в мир поэзии.

\section{Литература}

Али, Мухаммед Курд, (2010). Абу аль-Ала аль-Маари, «Поэт философов и философ поэтов. // Журнал аль-Муктасеб № 53, Дамаск, 1910.

Аль-Аббаси, Абир Абдулла Абдул-Вахаб, (2017). Халиф и астролог: политика автономной астрологии в начале эры Аббасидов - Халиф Аль-Мансур и стимулирование культуры предсказаний. - Академия социальных и гуманитарных исследований, 18-й выпуск.

Аль-Аккад, Аббас Махмуд (2009). Часы среди книг. - Египет: «Нахза».

Аль-Джабри, Мухаммед Абед, (2019). Формирование арабского разума. - 14-е издание - Бейрут: Центр исследований арабского единства.

Аль-Кафти, (1950). О передатчиках по словам грамматиков, расследование Мухаммеда Абу аль-Фадля Ибрагима. Египет: Дар аль-Кутуб.

Аль-Куртуби, (2006). Жами аль-Ахкам аль-Куран. расследование: Абдулла бин Абдул Мохсен аль-Турки. - Ливан:АльРисала Пресс.

Аль-Омари, Ибн Фадлаллах, (1951). Пути проницательности в различных государствах. - Бейрут: Дар.

Аль-Кутуб Аль-Ильмия. Resala.

Аль-Файруз Абади,(2005). Всеобъемлющий словарь.-Бейрут-Ливан: Фондпечати, распространения и распространения

Аль-Фараби, (1986).Послание о разуме. - Бейрут: Дар аль-Машрик.

Аль-Харави, Абу Исмаил, (1988). Достоинства путников. - Бейрут: Дар Аль-Кутуб Аль-Ильмия.

Голанян, Рахима, (2019). Особенности мудрости в доисламской поэзии и современной поэзии. - Иран: Журнал современных исследований литературы, № 40. 
Джабри, Шафик, (1930). Аль-Мутанабби - наполнитель мира и вдохновитель людей. - Сирия: Библиотека Аль-Шарк. Зидан, Джерджи, (1996). История арабской литературы. - Каир: Дар аль-Хилаль.

Ибн Манзур, (1980). Лисан аль-Араб. - Каир: Дар аль-Маариф.

Мандур, Мохамед, (2007). Систематическая споры между арабами. - Каир: Египетское общее книжное управление.

Мухаммед Абд аль-Хади Абу Рида, (1950). Аль-Кинди и его философия. - Египет:Дар аль-Фикр аль-Араби.

Мухаммед Камаль Хилми Бей, (1921). Абу аль-Тайиб аль-Мутанаби: его жизнь, творчество, поэзия и стиль. - Каир:

Молодежная библиотека и пресса.

Тахер, Хамед, (2014). Мудрость в поэзии Аль-Мутанабби. - Каир: Мустафа Аль-Халаби.

Хуссейн, Шаллуф, (2005). Поэзия мудрости аль-Мутанабби между ментализмом и техническими требованиями. Алжир:Университет имени братьев Монтури - Константин - Колледж искусств и наук // Журнал факультета арабского языка. Шамс ад-Дин, Ахмед, (1990). Аль-Фараби: жизнь, труды, философия. - Бейрут: Дом научной книги.

Эль-Бади\&\#39;и, (1964). Ясная заря о сущности Аль-Мутанабби. - Каир: Дар Аль-Маареф.

\section{References}

Ali, Muhammad Kurd, (2010). Abu al-Ala al-Maari, Poet filosofov i filosof poetov [Poet of philosophers and philosopher of poets] // Al-Muqtaseb Journal No. 53, Damascus, 1910.

Al-Abbasi, Abir Abdylla Abdyl-Vahab, (2017). Halif i astrolog: politika avtonomnoi astrologii v nachale ery Abbasidov - Halif Al-Mansyr i stimylirovanie kultyry predskazani. [Caliph and astrologer: the policy of autonomous astrology at the beginning of the Abbasid era] - Akademia sosialnyh i gymanitarnyh issledovani, 18-i vypysk. [Academy of Social and Humanitarian Studies, 18th edition]

Al-Akkad, Abbas Mahmyd (2009). Chasy sredi knig.[ A clock among books] - Egipet:«Nahza».

Al-Jabri, Myhammed Abed, (2019). Formirovanie arabskogo razyma. 14-e izdanie [The formation of the Arab mind. 14th Edition] - Beiryt: Sentr issledovani arabskogo edinstva.

Al-Kafti, (1950). O peredachikah po slovam grammatikov, rassledovanie Myhammeda Aby al-Fadla Ibragima. [On the transmitters according to grammars, the investigation of Muhammad Abu al-Fadl Ibrahim] -Egypet: Dar al-Kytyb.

Al-Kyrtybi, (2006). Jami al-Ahkam al-Kyran. Abdylla bin Abdyl Mohsen al-Tyrki. - Livan:Al-Risala Press.

Al-Omari, Ibn Fadlallah, (1951). Pyti pronisatelnosti v razlichnyh gosydarstvah [Ways of insight in different states]. - Beiryt: Dar Al-Kytyb Al-Ilmia.

Al-Fairyz Abadi, (2005). Vseobemlushi slovar. [Comprehensive Dictionary]- Beiryt - Livan: Fond pechati, rasprostranenia i rasprostranenia Resala.

Al-Farabi, (1986).Poslanie o razyme. [Message of the Mind]- Beiryt: Dar al-Mashrik.

Al-Haravi, Aby Ismail, (1988). Dostoinstva pytnikov. [Advantages of travelers.]- Beiryt: Dar Al-Kytyb Al-Ilmia.

Golanan, Rahima, (2019). Osobennosti mydrosti v doislamskoi poezii i sovremennoi poezii. [Features of wisdom in pre-Islamic poetry and modern poetry] - Iran: Jyrnal sovremennyh issledovani literatyry, № 40 .

Jabri, Shafik, (1930). Al-Mytanabbi - napolnitel mira i vdohnovitel ludei. [Al-Mutanabbi is the filler of the world and the inspirer of people] - Siria: Biblioteka Al-Shark.

Zidan, Jerji, (1996).Istoria arabskoi literatyry. [History of Arabic Literature] - Kair: Dar al-Hilal.

Ibn Manzyr, (1980). Lisan al-Arab. - Kair: Dar al-Maarif.

Mandyr, Mohamed, (2007). Sistematicheskaia spory mejdy arabami. [Systematic disputes between Arabs] - Kair: Egipetskoe obshee knijnoe ypravlenie.

Myhammed Abd al-Hadi Aby Rida, (1950). Al-Kindi i ego filosofia. [Al-Kindi and his philosophy]-Egipet:Dar al-Fikr al-Arabi.

Myhammed Kamal Hilmi Bei, (1921). Aby al-Taiib al-Mytanabi: ego jizn, tvorchestvo, poezia i stil. [Abu al-Tayyib al-Mutanabi: his life, work, poetry and style] - Kair: Molodejnaia biblioteka i pressa.

Taher, Hamed, (2014). Mydros v poezii Al-Mytanabbi. [Wisdom in the poetry of Al-Mutanabbi] - Kair: Mystafa Al-Halabi.

Hyssein, Shallyf, (2005). Poezia mydrosti al-Mytanabbi mejdy mentalizmom i tehnicheskimi trebovaniami. [The poetry of alMutanabbi's wisdom between mentalism and technical requirements] - Aljir:Yniversitet imeni bratev Montyri - Konstantin - Kollej iskysstv i nayk - Jyrnal fakulteta arabskogo azyka

Shams ad-Din, Ahmed, (1990). Al-Farabi: jizn, trydy, filosofia. [Al-Farabi: life, works, philosophy] - Beiryt: Dom naychnoi knigi.

El-Badi'i, (1964). Asnaia zara o syshnosti Al-Mytanabbi.[A clear dawn on the essence of Al-Mutanabbi] - Kair: Dar Al-Maaref. 